\title{
KEMITRAAN SEKOLAH DAN ORANG TUA SEBAGAI BENTUK PENINGKATAN KUALITAS PENDIDIKAN PESERTA DIDIK
}

\author{
Rahimah \\ 2010128220022@mhs.ulm.ac.id \\ Prodi Pendidikan Ilmu Pengetahuan Sosial, FKIP Universitas Lambung Mangkurat
}

\begin{abstract}
Abstrak
Kemitraan sekolah dan orang tua dalam penanaman kedisiplinan anak. Penelitian ini bertujuan agar mengetahui manfaat dari kemitraan sekolah dan orang tua sebagai bentuk penanaman kedisiplinan siswa. Metode yang digunakan studi kepustakaan ataupun kebanyakan orang mengatakan literature review yang dipaparkan secara deskriptif mengenai kemitraan sekolah dan orang tua dalam upaya meningkatkan kualitas pendidikan peserta didik. Hasil dari penulisannya adalah sebagai bentuk penanaman kedisiplinan anak dalam hidupnya dari jalinan antara kemitraan sekolah dan orang tua.
\end{abstract}

Kata kunci: kemitraan sekolah, kualitas pendidikan, peserta didik PENDAHULUAN

Orang tua adalah sebagai seorang yang mendidik anak yang memiliki peran penting, namun karena orang tua juga memiliki keterbatasan dan perlu hal yang banyak dalam persiapannya. Sehingga perlunya orang lain dan wadah dalam menanganinya seperti guru dan sekolah. Namun kedua hal antara orang tua dan guru memiliki kerjasama yang penting agar lebih tercapainya dalam tumbuh dan kembang anak tersebut.

Pada tahun 2015 pemerintah telah melakukan upaya dalam melibatkan orang tua di dalamnya sebagai fungsi dari adanya jalinan komunikasi dalam mengupayakan kemajuan belajar anak dan melibatkan orang tua dalam aktivitas belajar agar lebih efektif dan efisien. Terlibatnya orang tua di lingkungan sekolah dapat meningkatkan prestasi yang sangat bermanfaat bagi sekolah dan kedisiplinan anaknya.

Pendidikan bagi anak harus dilaksanakan secara berkelanjutan, berkesinambungan dan terprogram oleh semua pihak yang ada di dalamnya. Pendidikan merupakan pertanggungjawaban bersama keluarga, masyarakat dan pemerintah. Hal ini sebagai bentuk pencaharian pengetahuan. Berdasarkan Peraturan Menteri Pendidikan dan Kebudayaan Republik Indonesia No. 81A Tahun 2013 tentang pelaksanaan kurikulum baru yaitu kurikulum 2013. Hal ini mengatur tentang terlibatnya orang tua dengan 
sekolahnya yang akan bekerja sama agar sebuah tujuan dalam penambahan dari pemantapan materi pelajaran yang dipelajari dan diajarkan di lingkungan sekolah maupun diluar.

Guru dan orang tua melakukan sebuah kerja sama agar tercapainya sebuah tujuan proses pembelajaran yang baik dan hasilnya pun juga maksimal. Menurut Purwo (2018) mengatakan bahwa ada skemanya, yaitu: interaksi orang tua dalam pembelajaran, terlibatnya orang tua dalam pembelajaran dan penilaian orang tua terhadap kompetensi anak. Peningkatan kualitas pendidik merupakan sebuah tanggung jawab bagi semuanya.

Sikap teladan yang ditunjukkan oleh seorang guru dapat mempengaruhi tumbuh kembangnya seorang anak dalam sebuah pembentukan karakter anak terhadap sikap pribadi anak tersebut. Hal demikian lah seorang guru harus memberikan teladan yang baik terhadap anak didik. Tidak hanya seorang guru yang berperan disini, namun juga peran dari orang tua sangat diperlukan sehingga hasil dari penelitian dalam penulisan ini membuat adanya kemitraan sekolah dan peran orang tua dalam meningkatkan kualitas peserta didiknya dalam hal kedisiplinan dan lainnya (Abbas, E. W. 2013).

\section{METODE}

Jenis penulisan yang dilakukan pada artikel ini adalah studi kepustakaan ataupun kebanyakan orang mengatakan literature review yang dipaparkan secara deskriptif mengenai kemitraan sekolah dan orang tua dalam upaya meningkatkan kualitas pendidikan peserta didik (Arisanty, D.,\& Mutiani, M, 2021). Dan materi yang diambil pada penulisan ini bersumber dari artikel dan jurnal yang relevan sesuai apa yang dibahas. Objek dari penulisan ini adalah kualitas dari peserta didik. Pada penulisan ini menggunakan teknik yang diawali dari mengumpulkan beberapa sumber artikel dan jurnal yang relevan untuk diangkat. Selanjutnya sumber tadi di kaji, di analisa, dan di telaah kerelevanannya dengan apa topik yang dibahas. Data yang sudah terkumpul tadi di analisis dan disusun secara deskriptif dalam penulisan artikel sesuai apa yang telah ingin di angkat.

\section{PEMBAHASAN}

Kemitraan sekolah dan orang tua adalah bagian dari sebuah pendidikan. Hal demikian juga termasuk pada Tripusat pendidikan yang berarti bahwa tiga bagian dari hal 
yang bertanggung jawab atas sebuah pendidikan yaitu keluarga, sekolah dan masyarakat. Istilah Tripusat pendidikan di pakai oleh Ki Hajar Dewantara. Sekolah dan keluarga harus saling menjalin hubungan timbal balik yang baik agar menjadikan hal yang positif untuk sebuah tujuan pendidikan yang mengarah ke dalam hal bentuk kerja sama atau kemitraan di sekolah (Sarbaini, S., ABBAS, E. W., Wahyu, W., \& SOFYAN, A. 2020).

Kemitraan merupakan sebuah bentuk dari interaksi sosial yang bertujuan dalam mendidik peserta didik di dunia pendidikan. Orang tua menjadikan sekolah sebagai lembaga yang mendidik anaknya (Marzuki, M. 2017). Adapun bentuk strategi dalam hal menjalankan sebuah komunikasi yang baik adalah dengan melakukan sebuah pertemuan antara guru dan orang tua siswa, ikutnya orang tua sebagai partisipan yang ada di sekolah, dan hal lainnya. Tentunya tidak semua orang tua mampu memberikan pengetahuan dan pendidikan terhadap anak. Hal demikian karena keterbatasan pengetahuan yang dimiliki oleh orang tua sehingga pendidikan anak harus tetap berjalan dengan anak tersebut bersekolah (Abdullah, A. 2018).

Di lingkungan sekolah dan keluarga anak akan mempelajari banyak hal. Di mana nilai tersebut akan dipelajarinya secara teoritik tetapi mereka juga akan mengalaminya dan juga merasakannya secara langsung. Seperti adanya nilai kedisiplinan terhadap anak karena dengan adanya nilai disiplin ini anak akan dapat menatap hidupnya secara baik terutama disiplin dalam beribadah (Abdullah, A. 2018). Penanaman dalam kedisiplinan anak beribadah akan membuat perilakunya tertib dan patuh dalam beribadah sesuai dengan syariat Islam. kedisiplinan dalam Islam sangat tercermin jika orang tersebut tertib dalam menjalankan ibadah agamanya.

Tentunya tujuan dari sebuah pendidikan tidak akan pernah lepas dari adanya penanaman kedisiplinan dalam beribadah. Penanaman ini ditujukan sebagai bentuk dalam pendidikan agama sebagai sebuah dari proses yang harus dilakukan oleh anak secara terus-menerus dan akan berlanjut untuk kedepannya. Adapun bentuk dari program kegiatan sekolah yang dilakukan dalam menjalin kemitraan dengan orang tua pada proses menanamkan sikap disiplin beribadah adalah sebagai berikut.

a. Pertemuan Guru dan Orang Tua yang rutin dilakukan setiap tahunnya. Kegiatan yang dilakukan tidak hanya sekedar pada pemberian rapor anak dan penerimaan peserta didik baru. Namun, acara sosialisasi dari program sekolah maupun dari bidang 
sekolah seperti kurikulum juga bisa dijadikan ajang silaturahmi antara guru dan orang tua. Pada pertemuan ini juga diadakan sosialisasi program sekolah yang meliputi adanya semua program sekolah yang dimulai dari kegiatan belajar mengajar, ekstrakurikuler, kegiatan keagamaan. Hal demikian ia lakukan agar orang tua dan guru bersepakat tentang perencanaan kegiatan yang akan dilakukan di sekolah sebagai bentuk penanaman kedisiplinan kepada anak.

b. Partisipasi orang tua pada acara sekolah. Dengan adanya keterlibatan orang tua dalam mewujudkan dukungan serta kerja sama orang tua dalam dunia pendidikan. Orang tua dapat berpartisipasi pada kegiatan bakti sosial yang rutin diadakan oleh sekolah. adanya partisipasi orang tua ini sebagai bukti atas dukungan orang tua secara moril dan materiil kepada anak secara langsung pada kegiatan yang diadakan tersebut. Hal demikian karena orang tua tidak hanya mengetahui tentang kurikulum dalam pembelajaran tetapi juga adanya keterlibatan orang tua dalam memberikan dukungan terhadap anak. Adanya orang tua terlibat dalam aktivitas di sekolah maka akan memberikan korelasi yang erat tentang keberhasilan dari anak tersebut di lingkungan sekolah baik itu secara akademis maupun non-akademis.

c. Adanya sebuah perkumpulan antara orang tua dan guru yang dibentuk sebuah komite sekolah. Yang di mana pada setiap tahunnya Sekolah akan mengadakan rapat dengan komite dalam melaporkan dari hasil aktivitas pembelajaran dan aktivitas lainnya yang dilakukan di lingkungan sekolah.

Untuk melakukan kemitraan sekolah antara guru dan orang tua tentunya ada faktor pendukung dalam keberhasilan kemitraan sekolah dan orang tua tersebut dalam penanaman kedisiplinan ibadah terhadap anak. Ada beberapa faktor pendukung dalam keberhasilan tersebut (Handayani, I. P., \& Hasrul, H. 2021), yaitu:

\section{a. Kompetensi sosial guru}

Seorang guru harus memiliki kompetensi sebagai bentuk dalam mewujudkan keberhasilan di dunia pendidikan yang di mana guru melakukan pengarahan serta pembinaan dalam proses pengajaran sehari-hari terhadap anak. Sikap yang diberikan guru harus memperhatikan anaknya dengan penuh perhatian, kasih sayang, mengerti dan memahami apa yang menjadi keluhan dan kendala dari anak tersebut serta mampu memberikan solusi dan bantuan jika anak tersebut memerlukan bimbingan sehingga dapat meningkatkan rasa semangat dan kedekatan emosional guru sehingga membuat 
anak tersebut dapat mematuhi dan menghormati seorang guru (Rahman, A. M., Mutiani, M., \& Putra, M. A. H. 2019).

b. Perhatian orang tua terhadap minat anak

anak dan orang tua harus memiliki tujuan yang sama sesuai dengan minat dan bakat yang dimiliki anak tersebut sehingga anak tersebut dapat menjalankan dengan baik karena tanpa dukungan dari orang tua anak tersebut tidak akan menjalankan dengan baik sehingga adanya sikap keterbukaan antara orang tua dan anak dalam mengemukakan permasalahan yang dihadapi.

c. Terbukanya akses orang tua terhadap lingkungan sekolah

Sekolah harus memberikan akses yang luas terhadap orang tua agar terjadinya kemitraan antara orang tua dan sekolah yang berjalan dengan lancar. Misalnya akan diadakan aktivitas sekolah yaitu bakti sosial Hal tersebut harus dapat persetujuan dari orang tua anak agar terjadinya keterbukaan dan persetujuan serta saran yang masuk untuk aktivitas bakti sosial tersebut.

Tentunya dalam upaya meningkatkan kedisiplinan anak ada faktor yang menjadi penghambat dan hal tersebut harus diatasi agar tetap tercapainya tujuan terhadap pendidikan anak dalam meningkatkan kedisiplinannya (Hatimah, I. 2016), yaitu: 1) tingkat pendidikan dari orang tua yang masih rendah dan 2) beban administrasi guru. Oleh sebab itu, perlu segera diatasi agar permasalahan tersebut dapat teratasi. Adapun untuk hasil dari sebuah adanya jalinan kemitraan sekolah dan orang tua dapat membangun kedisiplinan siswa, bentuk kepercayaan diri mereka dan meningkatkan motivasi anak untuk berprestasi. Strategi orang tua dan masyarakat adalah komunikasi efektif dan kemitraan efektif (Rihatno, T., \& NURAINI, S. 2017).

\section{KESIMPULAN}

Kemitraan sekolah dan orang tua adalah bagian dari sebuah pendidikan. Hal demikian juga termasuk pada Tripusat pendidikan yang berarti bahwa tiga bagian dari hal yang bertanggung jawab atas sebuah pendidikan yaitu keluarga, sekolah dan masyarakat. Istilah Tripusat pendidikan di pakai oleh Ki Hajar Dewantara. Kemitraan merupakan sebuah bentuk dari interaksi sosial yang bertujuan dalam mendidik peserta didik di dunia pendidikan. Orang tua menjadikan sekolah sebagai lembaga yang mendidik anaknya. Adapun bentuk dari program kegiatan sekolah yang dilakukan dalam menjalin kemitraan 
dengan orang tua pada proses menanamkan sikap disiplin beribadah adalah sebagai berikut adalah pertemuan Guru dan Orang Tua yang rutin dilakukan setiap tahunnya, Partisipasi orang tua pada acara sekolah dan adanya sebuah perkumpulan antara orang tua dan guru yang dibentuk sebuah komite sekolah. Ada beberapa faktor pendukung dalam keberhasilan tersebut, yaitu: kompetensi sosial guru, perhatian orang tua terhadap minat anak dan terbukanya akses orang tua terhadap lingkungan sekolah.

\section{DAFTAR PUSTAKA}

Abbas, E. W. (2013). Ersis Warmansyah Abbas. PENDIDIKAN KARAKTER, 19.

Abdullah, A. (2018). KEMITRAAN GURU PENDIDIKAN AGAMA ISLAM DAN ORANG TUA DALAM PEMBINAAN KEAGAMAAN SISWA. Kalam: Jurnal Agama dan Sosial Humaniora, 6(2).

Handayani, I. P., \& Hasrul, H. (2021). Analisis kemitraan guru dan orang tua dalam pembentukan karakter anak berdasarkan Kurikulum 2013 di SMA. Jurnal Pembangunan Pendidikan: Fondasi dan Aplikasi, 9(1).

Hatimah, I. (2016). Keterlibatan keluarga dalam kegiatan di sekolah dalam perspektif kemitraan. PEDAGOGIA, 14(2).

Marzuki, M. (2017). Kemitraan Madrasah Dan Orang Tua Dalam Menanamkan Kedisiplinan Ibadah Siswa Ma Asy Syafi'iyah Kendari. Al-TA'DIB: Jurnal Kajian Ilmu Kependidikan, 10(2).

Nababan, Z. A. H., Arisanty, D., \& Mattiro, S. (2021, February). Human, Space, and Environment: Literature Review Through Exploring the Theme in Social Studies. In The 2nd International Conference on Social Sciences Education (ICSSE 2020) (pp. 163-166). Atlantis Press.

Pratiwi, N. D. (2016). KeMItRAAN SeKolAH DAN oRANg tuA DAlAM PeNANAMAN KeDISIPIINAN IBADAH SISWA SMA NegeRI 5 YogYAKARtA. Jurnal Pendidikan Agama Islam, 13(2), 145-156.

Rahman, A. M., Mutiani, M., \& Putra, M. A. H. (2019). Pengaruh kompetensi pedagogik dosen terhadap motivasi belajar mahasiswa pendidikan IPS. Jurnal Darussalam: Jurnal Pendidikan, Komunikasi dan Pemikiran Hukum Islam, 10(2), 375-387. 
Rihatno, T., \& NURAINI, S. (2017). Pengembangan Model Kemitraan Sekolah Dan Orangtua Pada Pendidikan Anak Usia Dini. Jurnal Pendidikan Usia Dini, 11(1), 117-128.

Sarbaini, S., ABBAS, E. W., Wahyu, W., \& SOFYAN, A. (2020). PENDIDIKAN KARAKTER.

Subiyakto, B., Abbas, E. W., Arisanty, D., Mutiani, M., \& Akmal, H. (2020). Sungai dan Kehidupan Masyarakat Banjar: Penguatan Lokalitas dalam Wacana Pendidikan IPS yang Responsif. 